\title{
A Study on Internet Usage Pattern among Students at the Medical University of Ilam and Influential Factors
}

\author{
Farahnaz Safarpour ${ }^{1}$, Nematullah kurd ${ }^{1}$ and Zeynab Ghazanfari ${ }^{2,3 *}$ \\ ${ }^{1}$ Department of Occupational Health, Faculty of Health, Medical University of Ilam, Iran \\ ${ }^{2}$ Department of Health Education and Health Promotion, Faculty of Health, Medical University of Ilam, Iran \\ ${ }^{3}$ Psychosocial Injuries Research Center, Medical University of Ilam, Iran
}

*Corresponding author: Zeynab Ghazanfari, Department of Health Education and Health Promotion, Faculty of Health,

Psychosocial Injuries Research Center, Medical University of Ilam, Ilam, Iran

\section{ARTICLE INFO}

Received: 蔧 January 18, 2021

Published: 幽 January 25, 2021

Citation: Farahnaz Safarpour, Nematullah kurd, Zeynab Ghazanfari. A Study on Internet Usage Pattern among Students at the Medical University of Ilam and Influential Factors. Biomed I Sci \& Tech Res 33(2)-2021. BJSTR. MS.ID.005388.

Keywords: Student; Internet Usage; University; Ilam

\section{ABSTRACT}

Introduction: Today, the Internet affects the main aspects of student life, including work, study, leisure, and social activities. The aim this study is to understand the internet usage pattern among students. Obtaining detailed information about this group of internet users and also identifying the current challenges in using internet can support us to design new policies to improve the using internet.

Materials \& Methods: This is a descriptive-analytical study on 481 students at the Medical University of Ilam, who were selected through the census method. The data collection tools were a research-made questionnaire and a checklist of website services. The Mann-Whitney and Kruskal-Wallis tests and the SPSS software were employed for the final analysis of the data and the inter-variable relationships.

Findings: The Internet usage pattern among students indicated an average 10-hour usage on a weekly basis (i.e. 11 hours for male students and 8 hours for female ones). $31.5 \%$ of the participants reportedly use the Internet for assignments. Only $22.5 \%$ had already taken computer courses, while $72 \%$ were willing to do so. In addition, half of the participants were satisfied with internet connection speed.

Discussion \& Conclusion: The high Internet usage rate among students necessitates adopting effective strategies for planning, training, website development not only in university departments but also in dormitories and organizing internet search workshops with the ultimate aim of directing a potentially educated workforce toward social development.

\section{Introduction}

Definitely one of the major modern technological achievements is the phenomenon of global information highway called the Internet. Today's academicians are deeply dependent on internet infrastructures to get the necessary information. The Internetallows access to scientific sites and national/international databases and journals. Regarding the key role of the Internet in access to the up-to-date information and establishing effective communication between scientists and experts in various fields, it is absolutely necessary to gain a deeper understanding of internet advantages and disadvantages for users [1]. Given the ever-increasing numbers of internet users for possible rapid and easy access to information, the level of Internet access is thus considered one of the main indicators of educational development [2]. The studies in the United States found that the youth are the biggest group of users. There are a surprisingly growing number of internet users, which was reported to equal 665 million worldwide by December 2000 [3]. A high percentage of internet users are students. The Internet currently has various applications in the academic world, such as electronic mail, access to the scientific articles, online textbooks, websites, electronic learning, etc. [3].

The statistics show that Iran with a population of 76,932,300 (according to the 2010 Census) has the highest internet usage 
rate $(52.5 \%)$ in the Middle East with an internet penetration rate (IPR) of $43.2 \%$, which corresponds to the percentage of the total population of a given country or region using the Internet [4]. IPR was reported to be $11.1 \%$ and $17.6 \%$ in the province of Ilam in 2008 and 2010, respectively [5]. The number of users grew by $189.13 \%$ during 2000-2010 [4], which emphasizes the necessity to pay wider attention to internet users and services. Today, the Internet affects the main aspects of student life, including work, study, leisure, and social activities. Therefore, a question arises as to "What is the internet usage pattern among students?" Getting new information to answer this question can help us to devise and implement useful interventions to improve the using internet. An analytical approach to this issue is to study the internet usage pattern among students and to investigate its positive and negative effects on the learning process with a focus on the concept of information literacy, i.e., the knowledge and skills required for using the Internet [6].

\section{Materials \& Methods}

This is a descriptive-analytical study on 481 students, who have used the computer labs of the Medical University of Ilam (including the faculties of health, nursing, and paramedical and medical sciences, central library, and dormitories). The data collection tools were a researcher-made questionnaire consisting of 37 questions on demographic and educational information, factors affecting the internet usage rate, services provided by computer labs, user satisfaction levels, obstacles to the optimal use of computer labs, and also a checklist for the hardware and software systems of computer labs. The study's inclusion criteria were to have been a university student for at least two academic semesters and to participate in the study voluntarily. For each computer lab (as the study field) one questioner was employed. All the questioners attended an orientation session to understand the structure of the questionnaire in order to ensure the validity of the data collected by them.

They were then present and began to collect information from all the people at the labs, after gaining the related approval of authorities to pursue the study's objectives with the questionnaire. Each participant only completed one questionnaire. After sample selection, adequate explanations were provided as to how to complete the questionnaire, and the participants were assured that their collected information would be anonymous, and the confidentiality would be maintained. In the next step, the

Table 1: Internet usage conditions. questionnaires were distributed after obtaining the participants' written consent. The SPSS software was then employed to analyze the data and the inter-variable relationships.

\section{Findings}

481 students, who were using the computer labs, participated in this study with an average age of 21 and an average GPA of 15.96 (out of 20). According to the results, $6.3 \%$ of the participants were studying for an associate degree, $82.84 \%$ for a bachelor's degree, $1.07 \%$ for a master's degree, and $8 \%$ for a Ph.D. In terms of gender, $42.1 \%$ were male and $57.8 \%$ were females. As regards the marital status, $92 \%$ were single and the rest (8\%) were married. Finally, $83 \%$ resided in dormitories, $15 \%$ with their family, and $0.6 \%$ with other students.

The inter-variable relationship between internet usage rate and paternal income/educational level revealed a significant correlation between these variables $(\mathrm{P}=0.04)$. This means that the higher the income/educational level, the higher the internet usage rate. The relationship between internet usage rate and the average of previous semester was also found to be significant $(\mathrm{P}=0.000)$, those with higher average had spent more/less time for internet, whereas no relationship were found between internet usage rate and the variables of educational stage, residency status, faculty, and marital status $(\mathrm{P}<0.05)$.

Male students reported an 11-hours internet usage rate on a weekly basis, which is a higher rate than that of female ones (8 hours). The Chi-squared test signaled an even bigger difference between female and male students in terms of internet usage $(\mathrm{P}=$ 0.000). The most common impact of computer usage is eyestrain, which was reported by $42 \%$ of the participants. Table 1 covers the results regarding the type of internet connection, usage rate, usage purpose, usage impact, and the time the participants were using the labs. Only $22.5 \%$ of the participants had self-reportedly taken computer courses. $80 \%$ believed that training courses can influence internet usage patterns, while $72 \%$ were willing to attend related courses. The difficulty level of internet access at the university was reported to be either easy (43\%) or normal (43\%) equally. Moreover, the students were asked to show their level of satisfaction about the following medical university of Ilam' services: the student affairs management system (SAMA), digital library, office automation system, faculty evaluation system, and so forth (Table 2).

\begin{tabular}{|c|c|c|}
\hline Variable & & Number (percentage) of Participants \\
\hline \multirow{2}{*}{ Type of internet connection } & Wireless & $313(64.7)$ \\
\cline { 2 - 3 } & Wired & $140(28.9)$ \\
\cline { 2 - 3 } & Both & $52(5.2)$ \\
\hline \multirow{2}{*}{ Weekly internet usage rate } & Female & 8.82 \\
\cline { 2 - 3 } & Male & 11.19 \\
\hline
\end{tabular}




\begin{tabular}{|c|c|c|}
\hline \multirow{4}{*}{ The time spent on the Internet at the university } & Leisure & $90(18.9)$ \\
\hline & $\begin{array}{l}\text { Information } \\
\text { search }\end{array}$ & $110(23.1)$ \\
\hline & Assignments & $150(31.5)$ \\
\hline & $\begin{array}{l}\text { Research } \\
\text { purposes }\end{array}$ & $126(26.5)$ \\
\hline \multirow{6}{*}{ The impacts of internet usage } & Dry eye & $17(3.5)$ \\
\hline & Headaches & $98(20.5)$ \\
\hline & Eyestrain & $201(42.1)$ \\
\hline & Insomnia & $95(19.9)$ \\
\hline & $\begin{array}{l}\text { Musculoskeletal } \\
\text { disorders }\end{array}$ & $50(10.5)$ \\
\hline & Anorexia & $17(3.6)$ \\
\hline \multirow{4}{*}{ The time of internet usage } & 8-11 am & $72(15.2)$ \\
\hline & $11-13$ & $192(40.6)$ \\
\hline & $13-$ & $27(5.7)$ \\
\hline & Other cases & $182(38.5)$ \\
\hline
\end{tabular}

Table 2: Internet usage satisfaction.

\begin{tabular}{|c|c|c|c|c|c|}
\hline & $\begin{array}{c}\text { Very low (number, } \\
\text { percentage) }\end{array}$ & $\begin{array}{c}\text { Low (number, } \\
\text { percentage) }\end{array}$ & $\begin{array}{c}\text { Medium (number, } \\
\text { percentage) }\end{array}$ & $\begin{array}{c}\text { High (number, } \\
\text { percentage) }\end{array}$ & $\begin{array}{c}\text { Very high (number, } \\
\text { percentage) }\end{array}$ \\
\hline Satisfaction with the speed of internet & $78(16)$ & $113(23)$ & $250(51)$ & $45(45)$ & $3(0.6)$ \\
\hline $\begin{array}{c}\text { Satisfaction with the student affairs } \\
\text { management system }\end{array}$ & $30(6.2)$ & $112(23)$ & $272(55.9)$ & $64(13.1)$ & $116(8)$ \\
\hline $\begin{array}{c}\text { Satisfaction with the office automation } \\
\text { system }\end{array}$ & $32(6.5)$ & $105(21.5)$ & $287(58.9)$ & $60(12.3)$ & $5(1)$ \\
\hline $\begin{array}{c}\text { Satisfaction with the central library } \\
\text { system }\end{array}$ & $67(14)$ & $118(24.2)$ & $217(44.6)$ & $73(15)$ & $11(2.3)$ \\
\hline $\begin{array}{c}\text { Satisfaction with the digital library } \\
\text { system }\end{array}$ & $67(13.9)$ & $130(27)$ & $226(46.9)$ & $53(11)$ & $6(1.2)$ \\
\hline $\begin{array}{c}\text { Satisfaction with the faculty evaluation } \\
\text { system }\end{array}$ & $108(22.1)$ & $150(30.7)$ & $186(38.1)$ & $34(7)$ & $8(1.6)$ \\
\hline
\end{tabular}

\section{Discussion \& Conclusion}

The present study aimed to investigate the internet usage rate and its impact on the academic achievements of students at the Medical University of Ilam in 2014. The study's results mainly revealed a weekly average of 10 hours spent by students on the Internet (11 hours for male students, and 8 hours for female ones). According to Movahed Mohammadi, et al. [7], this rate was reported to be $61-120$ minutes per week by $39 \%$ of the students at the Tarbiat Modares universities, similarly $61-120$ minutes by $23.5 \%$ at the University of Tehran, above 120 minutes by $32.4 \%$ at the University of Shiraz, and the same by $40 \%$ at the Isfahan University of Technology. Jafari, et al. [8] found a weekly average of 2.4 hours among the students at the Kabul University. The variable of gender affects internet usage rate, as reportedly the male students spent more hours on the Internet than the female ones. This is consistent with the research findings of Fayaz-Bakhsh, et al. [4], Bastani, et al. [9], and Mirghafoori, et al. [10].

It should be noted that there was no significant relationship between internet usage rate and the other variables, including age, educational stage, faculty, residency status, marital status, and educational status. $65 \%$ of the participants have self-reportedly access to wireless internet connections because most computer labs are equipped with wireless modems whereby students connect to the Internet with their laptops or mobile phones. The T-test results showed that $77.5 \%$ had never attended computer courses, which is indicative of apparent indifference to internet courses for raising awareness of valuable internet advantages. Ghahremani, et al. [3] also found that $67.4 \%$ of the students at Kabul University had never taken any computer or internet courses, while $73 \%$ were self-reportedly willing to do so since $80 \%$ considered it to be an influential factor in internet usage. Movahed Mohammadi, et al. [7] also reported a similar finding. In terms of applications, the participants indirectly provided a list in order of priority including leisure, information search, assignments, and research purposes.

This is consistent with Unnikrishnan [11], which can be expectably attributed to the fact that the Internet has become the second-most-popular common source of social life for many people all around the world. According to Fayaz-Bakhsh, et al. [4], 
$57.46 \%$ of the students reported that they mostly use the Internet for professional or educational purposes. Bagherzadeh, et al. [1] also reported that $36.7 \%$ of the time on the Internet was spent for education, $19.4 \%$ for leisure, $17.1 \%$ for news, $11.5 \%$ for email, $4.5 \%$ for chat, and $9.9 \%$ for other cases. Pouratashi, et al. [12] found that email, university website, and research, respectively, account for the most common activities. Ghahremani, et al. [3] showed that $65 \%$ of the students at Kabul University use the Internet for information search and research purposes. The T-test results indicate that $43 \%$ of the participants considered the difficulty level of internet access to be neither easy nor hard, while half of them were found to be moderately satisfied with the speed of the Internet. As regards the students' awareness of internet services, 55\% were self-reportedly unaware of antivirus services and only $60 \%$ were familiar with wireless systems.

It is of considerable importance to measure the level of user satisfaction with internet services in higher education institutions because this is a potentially key indicator of both the quality and quantity of such services provided by universities to students and other users. A high level of satisfaction signifies the acceptably high quality of services ensured by authorities' attention, whereas low levels indicate the existence of problems and barriers. The latter somehow directs the attention of authorities toward improving the services and eliminating the current barriers. The T-test results showed that $38 \%$ of the participants were satisfied with the faculty evaluation system. $44 \%$ were moderately satisfied with the central library system, while $30 \%$ expressed a low level of satisfaction. 58\% reported moderate satisfaction with the office automation system. $46 \%$ expressed moderate satisfaction with the digital library system. The T-test results also showed that $55 \%$ were moderately satisfied with the student affairs management system.

Overall, up-to-date software systems, which provide a userfriendly user interface, can greatly contribute to the satisfaction of students. According to the T-test results, $46 \%$ of the participants expressed satisfaction with the working hours of the labs while $53 \%$ were not satisfied. Due to limited staff even during office hours, students were not able to use the lab services after $2 \mathrm{pm}$. The T-test results showed that $60 \%$ of the participants were satisfied with the lab rules, whereas around $40 \%$ were not. There is an exclusive lab in each faculty, which means that the students are only allowed to use their faculty lab. The participants were found to be satisfied with this rule since it used to be possible that one student could use a computer for hours while another could not for the non-application of such limitations. The most common barriers to internet usage were a low ratio of computers to students (71.02\%), low internet connection speed (51.74\%), lack of broadband connections (37.99\%), unavailable personal computers (35.71\%), lack of computer skills (31.29\%), hardware problems (27.81\%), improper software $(27.35 \%)$, and other problems such as viral systems, unupdated systems, and lack of anti-filter software
(1.86\%). According to Bagherzadeh, et al. [1], the barriers were lowspeed connections, lack of training, difficult access to the Internet and computers, unavailable sites, and high costs.

$58 \%$ of the participants believed that the authorities are aware of the Internet requirements at the university. Ghahremani, et al. [3] also found the most important barrier to internet usage at Kabul University to be the low ratio of computers to students (66.20\%), respectively followed by "lack of internet access in all faculties" (59.80\%), "low speed internet connections" (42.70\%), "lack of free internet access in dormitories" (32.50\%), "indifference among university authorities to the development of internet services" (32.50\%), and "computer failure" (30.80\%). According to $8.10 \%$ of the users, the other barriers were the inappropriate and discriminatory attitude of computer lab managers toward students, unskilled and unaccountable technicians to deal with technical problems, lack of required software, and non-operation of labs during office hours. In addition, $34 \%$ on average were familiar with health-related databases like PubMed, Scopus, and Magiran.

It can be thus concluded that the high Internet usage rate among students necessitates adopting effective strategies for planning, training, website development not only in university departments but also in dormitories and organizing internet search workshops with the ultimate aim of directing a potentially educated workforce toward social development. The study also recommends focusing on other issues like internet addiction, lifestyle, and internet hazards among students for future research.

\section{References}

1. Bagherzadeh R, Dehghani L, Kholghi B, Afrasiabi Z (2011) Prevalence and obstacle of internet use for education in students of Bushehr University of Medical Sciences. Iranian Journal of Medical Education 11(2): 159-160.

2. Mennati moheb A, Zolghadr H (2011) The role and status of internet in teaching and research at universities, Case study: School of Civil Engineering. Iran University of Science and Technology 51: 143-167.

3. Ghahremani L, Jafari Baghkheirati A, Nazari M (2013) Internet addiction and its effect on the academic achievement students of Shiraz university of medical sciences: cross-sectional study on addiction-driven behaviors. Media 4(1): 44-51.

4. Fayaz-bakhsh A, Khajeh- kazemi, Soleymani nejad M, Rahimi F, Jahangiri L, et al. (2011) The internet using and health: student's knowledge, attitude and lifestyle related to the internet. Hakim Research Journal 14(2): 96-105.

5. (2011) Statistical Center of Iran. The results of internet users.

6. Ebrahim Abadi H (2009) The pattern of use internet: learning environment and the social and cultural context. Cultural Studies 2(7): 97-118.

7. Movahed mohammadi H, Iravani H (2002) A model for internet use by graduate students of selected agricultural faculties in Iran. Iranian J Agric Sci 33(4): 717-727.

8. Jafari M, Dayani MH (2010) Internet use by students of Kabul university. Library and Information Science 13(3): 179-204.

9. Bastani S, Mizban Sh (2007) Gap gender in using of computer and internet, study on Tehran University students. Journal of Women's Studies 5(1): 35-63. 
10. Mirghafoori SH, Shafiee Roodposhti M (2010) The analysis of gender gap in student internet users (case study: male and female students of Yazd university). Women Studies 1(2): 127-148.

11. Unnikrishnan B, Kulshrestha V, Saraf A, Agrahari AC, Prakash S, et al. (2008) Pattern of computer and internet use among medical students

ISSN: 2574-1241

DOI: 10.26717/BJSTR.2021.33.005388

Zeynab Ghazanfari. Biomed J Sci \& Tech Res

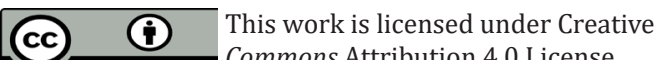

Submission Link: https://biomedres.us/submit-manuscript.php in Coastal South India. South East Asian Journal of Medical Education 2(2): $18-25$.

12. Pouratashi M, Movahed Mohammadi H (2007) Recognition and analysis of factors influencing the use of internet by female agricultural studies students. Womens' Studies 1(2): 103-120.

$\begin{array}{ll}\text { BIOMEDICAL } & \begin{array}{l}\text { Assets of Publishing with us } \\ \text { RESEARCHES }\end{array} \\ \text { - Global archiving of articles } \\ \text { - Immediate, unrestricted online access } \\ \text { - Rigorous Peer Review Process }\end{array}$

